\title{
ОСОБЛИВОСТІ ВИКЛАДАННЯ ДЛЯ ОФІЩЕРІВ ЗАПАСУ ХІРУРГІЧНОЇ ТАКТИКИ ПРИ ВОГНЕПАЛЬНІЙ ТА ВІДКРИТІЙ ТРАВМІ КІНЦІВОК
}

\author{
Я. С. Кукуруз, І. Й. Сличко, В. А. Яловенко \\ Український науково-практичний цеентр екстреної медичної допомоги та медицини катастроф, \\ м. Київ, \\ Ірпінськийвійськовийгоспіталь
}

\section{PECULIARITIES OF TEACHING FOR RESERVE OFFICERS OF SURGICAL TACTICS AT FIRE AND OPEN INJURY OF EXTREMITIES}

\author{
Ya. S. Kukuruz, I. Y. Slychko, V.A. Yalovenko \\ Ukrainian Scientific-Practical Centre of Emergency Medical Care and Medical of Catastrophes, Kyiv, \\ Irpin Military Hospital
}

\begin{abstract}
Виходячи з аналізу доступних джерел наукової інформації та спираючись на накопичений власний клінічний і бойовий досвід, автори констатують, що в сучасних збройних локальних конфліктах набула широкого застосування як вогнепальна, так і мінно-вибухова зброя. Поранення здебільшого мають обширний, поєднаний характер, і тому цілком логічно сучасну вогнепальну рану трактувати як вогнепальну травму.

У системі етапного лікування вогнепальних поранень виразно прослідковується тенденція до скорочення етапів медичної евакуації з застосуванням повітряного транспорту, який оснащений відповідним медичним обладнанням.

У системі кваліфікованої (спеціалізованої) медичної допомоги все більшого значення набуває застосування методики поетапної хірургічної обробки ран, в основі якої с методика "Damage Control".
\end{abstract}

Taking into account accessible sources of scientific information and gained own clinical and fighting experience, the authors ascertain that in current armed conflicts the wide spread use has both fire and mine-explosive arms. Injuries have mostly broad, combined nature, that's why it is logical to interpret the modern fire injury as fire trauma.

In the system of phase treatment of fire injuries it is clearly retraced the tendency to decrease the stages of medical evacuation using the air transport, that is equipped with proper medical outfit.

In the system of qualified (spesialised) medical care the wide spread significance has the use the methods of phase surgical debridement in basis of which is methods "Damage Control".

Вступ. У сучасному світі локальні війни та збройні конфлікти різного масштабу мають швидкоплинний за часом характер і являють собою поєднання високоманеврених бойових дій з використанням комплексних засобів ураження та високоточної зброї на всю глибину комунікацій протистоячого угруповання.

В останні десятиліття широкого застосування в збройних конфліктах, в тому числі і терористичних актах набула мінно-вибухова зброя (боєприпаси), яку за своїми наслідками можна віднести до неядерної зброї масового знищення.

Слід зазначити, що швидкими темпами удосконалюються і впроваджуються в арміях провідних країн світу принципово нові індивідуальні і колективні засоби захисту особового складу (бойової техніки), в тому числі і створені за нанотехнологіями (каски, бронежилети, бронеелементи для захисту суглобів, динамічна і електрична броня тощо).

Основна частина. Методичне забезпечення грунтується на аналізі етапного лікування 986 постраждалих з вогнепальною та відкритою травмою, переважно чоловічої статі, віком від 17 до 46 років, середній вік 26 років.

Переважна більшість лікувалась в ЦВШ ДРА, а продовжувала лікування і реабілітацію в колишніх 340 ОВШ ТуркВО, 408 ОВШ Київського округу, ККЛШМД.

Були досліджені травмогенез, нозологічні та клінікоанатомічні особливості вогнепальної травми у поранених, оцінена ефективність медичної допомоги та проведений аналіз недоліків в системі етапного лікування. 
В групі поранених з мінно-вибуховою травмою переважали поєднані пошкодження, по суті-вогнепальна травма.

Загальний тяжкий стан, крововтрата спостерігалися майже у 50 \% поранених. У клініко-нозологічній структурі переломи складали понад 35 \%, поранення магістральних судин - $7 \%$, периферичних нервів $12 \%$, обширні поранення м'яких тканин - в межах $40 \%$.

Вищезазначене зумовлює певні медично-організаційні засади, які повинні братися до уваги при розбудові системи етапного лікування поранених, зокрема з вогнепальною травмою кінцівок .

Всі ці далеко не в повному обсязі перелічені фактори визначають різноманітність поранень 3 позиції сучасної концепції хірургії пошкоджень, які, на думку провідних фахівців, слід трактувати як вогнепальні травми.

Таким чином суттєво змінюється нозологічна та клініко-анатомічна структура вогнепальної травми. Безумовно, вищенаведені обставини надзвичайно ускладнюють та обмежують можливості ВПХ і вимагають перебудови системи етапного лікування поранених відповідно до імовірної структури санітарних втрат в умовах конкретних бойових дій та інших, не менш важливих негативних факторів (кліматичних умов, санітарно-епідеміологічної ситуації тощо).

Взяти, наприклад, систему медичного забезпечення бойових дій, що вела 40 Армія ОКРВА, але ж вже перші бойові операції змусили ЦВМУ РА і керівництво медичною службою 40 Армії радикально перебудувати, а по суті заново організувати систему медичної допомоги пораненим, яка б відповідала вимогам цієї війни.

У перебудованій системі виразно прослідковується тенденція до скорочення етапів медичної допомоги, а точніше, обминання їх з використанням переважно повітряного транспорту та бронетехніки для евакуації поранених і майже цілковитої відмови від табельного санітарного транспорту, як найменше захищеного в умовах ворожого тилу. Найбільша увага приділена етапу першої медичної допомоги і виносу поранених в безпечне місце.

В таких умовах надання першої медичної допомоги, а головне, винесення пораненого з-під вогню вимагало значних зусиль. І хоча було чимало зроблено для забезпечення своєчасної дієвої медичної допомоги на цьому етапі (це і знаходження лікарського персоналу у передових підрозділах, евакуація поранених за допомогою “зависаючого” гелікоптера у важкодоступній гірській місцевості тощо, але ж про- блеми надання медичної допомоги пораненим в зоні бойових дій так і не були на належному рівні вирішені аж до кінця війни.

За даними, показання до ПХО були у 65 \% поранених. Найчастіше застосовувалися косо-поперечні розтини шкіри з використанням напрямку та конфігурації ранового каналу, а також способом “конвертування”, що забезпечувало достатній доступ до глибоких відділів рани. При пораненнях зі значними пошкодженнями ПХО завершувалося декомпресивними розтинами фастіальних футлярів, видаленням некротичних тканин, надійним гемостазом без цілковитого зашивання рани, яку тампонували змоченими в антисептику марлевими серветками. Якщо основні показники гемостазу (свідомість, дихання, гемодинаміка тощо) були компенсовані - ПХО завершували один $з$ видів МОС, найчастіше АЗФ. У нестабільних поранених протягом 1-2-х днів проводилася інтенсивна терапія, в тому числі оксибаротерапія (барокамера “Іртиш”) з наступними завершуючими операціями в часі: повторні $\mathrm{XO}$, репозиції уламків і $\mathrm{MOC}$, автодермопластика, усунення ускладнень (тромбоектомія, розкриття гематом, гнійних запливів тощо).

I яке місце посідають різні види МОС у лікуванні вогнепальних переломів - залишається остаточно невирішеною проблемою ВПХ. При цьому дискусійним питанням є застосування накісткових, занурюючих та інтрамодулярних видів МОС.

Щодо хірургічної тактики при відривах чи цілковитого руйнування дистальних сегментів кінцівок вважаємо найбільш раціональним клаптиково-циркулярну ампутацію без одномоментного цілковитого зашивання рани. Заслуговує уваги і кістково-пластична ампутація стегна за методикою Гріті-Шимановського при високих відривах чи руйнуваннях гомілки, колінного суглоба, як малотравматична 3 мінімальною інтраопераційною крововтратою. Ця операція дозволяє зберегти повноцінний м'якотканинний комплекс стегна. Таких операцій було виконано у 27 поранених 3 задовільними результатами. Щодо хірургічної тактики вогнепальних відривів чи цілковитого руйнування ступні заслуговує на увагу також кістковопластична ампутація за методикою Пирогова. 3 задовільними клінічними результатами було виконано 17 таких операцій з застосуванням АЗФ за Ілізаровим.

Результати лікування та ускладнення вогнепальних поранень кінцівок (прослідковано протягом 6 тижнів у майже 80 \% усіх поранених):

- первинне загоєння ран з стабілізацією основних показників гомеостазу та клінічних аналізів відмічено у $79 \%$ випадків; 
- в задовільному стані та середнього ступеня тяжкості евакуйовані до тилових госпітальних баз понад $70 \%$ поранених.

Ускладнення вогнепальних поранень кінцівок:

- нагноєння ран після ПХО - $21 \%$;

- газова гангрена - 0,5 \%;

- локальний остеомеліт - 17 \% (в т. ч. при занурених видах МОС - $3 \%$, АЗФ- $7 \%$ );

- 3 різних причин АЗФ змінювався на інші види іммобілізації- $8 \%$;

- пошкодження магістральних судин кінцівок у 5 випадках на 371 операцію застосування шпицевих АЗФ за Ілізаровим;

- жирова емболія - $7 \%$;

- тромбемболія - $5 \%$;

- респіраторний дистрес-синдром - $14 \%$;

- коагулопатія із загальною неконтрольованою кровотечею - $9 \%$;

- тромбоз (ретромбоз) магістральних артерій після відновлюючих операцій $-7 \%$;

-ішемічна гангрена після відновлювальних судинних операцій $-11 \%$;

- післяопераційна смертність - $9 \%$.

Причини летальних випадків вогнепальних поранень кінцівок:
- масивна крововтрата - 42,2 \%;

- вкрай тяжкі поєднано-множинні пошкодження $12 \%$

- обширні нагноєння та сепсис - 8,9\%;

- перитоніт у поранених з поєднаною абдоміно-скелетною травмою (домінуючі поранення органів черева)-16,7 \%.

Висновки: 1. В умовах бойових дій з застосуванням сучасних видів вогнепальної зброїпоранені в кінцівки складають понад 2/3 від усіх поранених. В порівнянні 3 війнами минулого, кількість тяжкотравмованих 3 поєднаними травмами зросла до 25-30\%, що пов'язане в першу чергу ззастосуванням високоточних боєприпасів і боєприпасів мінно-вибухової дії.

2. У лікуванні вогнепальних ран загалом показали себе з позитивної сторони себе класичні принципи ПХО, однак при обширних множинно-поєднаних пошкодженнях, що призводило до розвитку вторинних некрозів, доцільним було ХО виконувати в декілька етапів, з урахуванням загального стану пораненого та характеру місцевих пошкоджень.

3. Засади спеціалізованого лікування вогнепальних поранень кінцівок повинні грунтуватися на принципах реконструкції та відновлення анатомо-функціональних властивостей пошкоджених ділянок тіла. 